\title{
Notes on the foundation of the Federal Theological Seminary of Southern Africa (Fedsem)
}

G A Duncan

(University of Pretoria)

\section{ABSTRACT \\ Notes on the foundation of the Federal Theological Seminary of Southern Africa (Fedsem)}

The Federal Theological Seminary of Southern Africa was established in a changing and fluid situation in 1960s South Africa both politically and ecclesiastically. Its foundation can be attributed to the influence of these national and church influences. Politically, the changing context in the educational world in particular and ecclesiastically, a growing tendency towards ecumenism both nationally and internationally contributed to the need for an independent institution which would train ministers for the mainline churches in a deteriorating political context. In addition, there was a strong view that the influence of the Holy Spirit was operative in the political context which 'forced the church to be the church'.

'...it was a kairos moment that brought Fedsem into being in the early 1960s'(Ndungane 1998:115).

\section{INTRODUCTION}

To a large degree the formation of the Federal Theological Seminary of Southern Africa was a direct response to various pieces of legislation introduced by the Nationalist government which was elected in 1948. Foremost among these was the Group Areas Act, the Bantu Education Act, the Extension of Universities Act and the Fort Hare Transfer Act. In a real sense, these political developments forced the issue concerning ecumenical theological education. However, earlier ecumenical experiments had failed for a variety of reasons. A lack of sufficient resources in terms of personnel and finance was a serious issue in this regard. However, there was an ecumenical spirit at work which originated in the formation of the General Missionary Conference of South Africa in 1904 and at an international level from the Edinburgh conference of the International Missionary Council (IMC) in 1910. Alongside this, there was an external thrust from the Theological Education Fund of the IMC (supported by the Rockefeller Foundation) established to assist in the training of ministers in Asia, Africa and Latin America. In 
addition, there were strong ecumenical characters at work in the area of theological education. This article will investigate some of the forces that brought the Seminary into being as a limited ecumenical experiment based on an act of faith.

\section{THE INITIATIVE}

...it would be outrageous to suggest that the churches' new freedom to build together was worth the loss to the educational enterprise. In the presence of such sacrifice you don't compare gain and loss, you simply stand silent. We were compelled to recognize that the structures in which we found security might burden us with such a weight that we could not rise to a faithful response in changed conditions. And so what we would never have given up was taken from us, and it became clear that our only real security lay in faithfulness to the will of the church's Head (Booth 1973:3).

In the light of Fedsem's subsequent history this was an apt prophetic comment on the value of perseverance in adversity. It acknowledges that beyond a negative reason for the foundation of Fedsem there was a guiding hand at work.

In September - October 1953, two representatives of the International Missionary Council, Dr Norman Goodall and Rev Eric W Nielsen, visited South Africa with the purpose of ascertaining the current state of theological education. This was to be of enormous significance for the development of ecumenical theological education. Part of their report stated:

We were surprised to discover how slight is the contact between the theological colleges of the different areas and churches. Some college principals, even, were unaware of the existence of certain other colleges. Few theological teachers have ever met their colleagues in other institutions; rarely does there seem to have been a thorough and widely representative discussion of common problems, methods of work, literature resources and needs (Booth 1973:3).

However, Goodall and Neilsen had a clear vision of the type of minister that was needed to minister in the South African context. It was one who could analyse the problems faced by church members: 
in the light of the Word of God and be able to speak to them in the power of that Word. To do this he must be theologically trained in the deepest sense of the term. Such theology ... is an affirmation and unfolding of the Word in relation to the present moment in history and the circumstances amidst which it is spoken .... Both the theological student and the theological tutor must be deeply engaged in the problems and tensions of the situation to which this Christian message has to be spoken (Booth 1973:2).

By the formation of the Federal Theological Seminary of Southern Africa in 1963, the constituent churches took up the tradition inaugurated at Lovedale Missionary Institution and other well known institutions such as Healdtown and Tiger Kloof in the $19^{\text {th }}$ century of non-racial, ecumenical ministerial formation with a strong emphasis on academic excellence and practical training pursued with integrity:

It was, in many respects, the crowning achievement of a century of missionary based theological education, and a bold attempt at ecumenical theological formation (De Gruchy 1996:22).

This was a creative ecumenical response to the demise of the denominational theological colleges which 'encouraged the churches ... to face the future with nothing less than full, mutual trust and solidarity' (Madise 2000:49). Those churches were the Church of the Province of South Africa [Anglican], the Methodist Church of South Africa, the Bantu Presbyterian Church in South Africa, the Presbyterian Church of South Africa, the Congregational Union of Southern Africa, the London Missionary Society and the American Board Mission (Bantu Congregational Church).

In particular, the vision was the brainchild of Rev William Booth, Rev Charles W Ransom, Rev Seth Mokitimi and Rev John Summers. However, this vision was restricted to the black community as the English-speaking churches had already established an ecumenical department of divinity for their white students at Rhodes University in 1947 (Mouat 1999:221):

The segregation of theological education reflected the reality of segregation in the churches themselves, but FEDSEM was a symbol also of the churches' resistance to apartheid (De Gruchy 1997:159), 
particularly to apartheid legislation enshrined in the Bantu Education Act (1953), the Extension of University Education Act (1959), the University of Fort Hare Transfer Act (1959), the Urban Areas Act (1945) and the Group Areas Act (1950). A further factor in the inauguration of an ecumenical institution was a shortage of human and financial resources. This had been highlighted by the Goodall and Neilson Commission of the International Missionary Council (1953).

While the churches each had a distinguished history in theological education which had the potential to be continued and promoted at Fedsem, from 1963, it would be necessary to take account of the relationship with the University of Fort Hare (UFH) and its history in theological education as a significant factor in future development. Until 1953, Fort Hare students had been examined by the University of South Africa (UNISA). From 19521959, Rhodes University became the examining body. And in 1960, the Bantu Education Department (BED) took over control of Fort Hare and its hostels. At this time the Presbyterians, Methodists and Congregationalists took up temporary residence in Lovedale Bible School in order to establish the Lovedale United Theological School. Existing students were sent to Fort Hare to complete courses. New students went to study for diplomas and degrees while they took denominational lectures at the theological school. Occasionally, Lovedale staff lectured at Fort Hare.

In 1961, the BED commissioned a report on the 'theological needs of the Bantu'. After 1961, the courses taught at Fort Hare would come under the control of UNISA. This did not suit the needs of the English-speaking (Fedsem) churches with their simultaneous approach to academic and practical formation. It was anticipated that existing co-operation between the theological school and Fort Hare would be difficult to maintain after the opening of the Seminary (Academic Board Minute A3/S30/20/11/62, SECOND DRAFT MEMORANDUM PREPARED BY REV AJT COOK: THEOLOGICAL COURSES AT FORT HARE, University of Fort Hare [UFH], Howard Pym Africana Library [HPAL]).

\section{THE POLITICAL CONTEXT OF THE FORMATION OF FEDSEM}

While discussions concerning the control and content of the curriculum were taking place, the wider context of South Africa was 
seething with discontent. The Sharpeville Massacre took place on March 1960 and resulted in at least 69 black deaths and a state of emergency being declared. Later that year, the World Council of Churches sponsored a consultation of church delegations at Cottesloe, Johannesburg. This consultation produced a set of mild resolutions on race and justice which were rejected by the Dutch Reformed Church (DRC). This, in turn led to the formation of the ecumenical and activist Christian Institute (CI) under the direction of Ds Beyers Naudé. The Institute was later to be disowned by the DRC. The multi-racial Liberal Party was outlawed in 1968 and its moral stance was taken over by the CI which established the Study Project on Christianity in an Apartheid Society (Sprocas). These were initiatives taken by white people, partly because there was a growth of Black Consciousness which looked on white activism contemptuously.

The CI along with the National Union of South African Students (NUSAS), the Institute of Race Relations (IRR) and the University Christian Movement (UCM) attracted the hostility of the government due to their opposition to apartheid and the fact that they received funding from overseas. In 1972, the Prime Minister, B J Vorster, established the secretive Schlebusch Commission to investigate these organizations. Subsequently, a number of members of these organizations were banned. There seemed to be a rampant irrational fear in government circles of anything and anyone who held or promoted views which differed from its own.

On the international scene, significant changes were taking place in Portugal, Mozambique, Angola, Rhodesia and Namibia, and government insecurity was fuelled by the WCC's decision to instigate the Programme to Combat Racism through its support of liberation organizations. Within South Africa, Church-State relations deteriorated as the South African Council of Churches (SACC) passed a resolution in 1974 at its Hammanskraal meeting in which churches were urged to ask their members to consider refusing to take up arms to defend an unjust and discriminatory society.

\section{PREPARATIONS FOR THE FORMATION OF FEDSEM}

The original impetus for a joint seminary venture can be traced to 1957: 'A united seminary has been a vision of the Churches from the time the first meeting was convened to consider such a possibility in April 1957’ (Wing 1990:89-91). 
Early in 1959, Dr Charles Ransom of the Theological Education Fund visited South Africa and met with representatives of the member bodies of the Christian Council of South Africa. Having investigated theological education in the black context he outlined four possibilities. One of the four gained general acceptance at a meeting on 6 May 1959 of a committee formed to work out a plan to be presented to the churches. This involved a:

radical realignment of theological institutions which would bring a number of existing institutions into union on a federal basis on a common site (Memorandum on Proposed Federation of Theological Institutions at Present Training Non-white Students, The Christian Council of South Africa, 3 July 1959, FedSem AUC Box 35, UFH:HPAL).

In this sense, of being only for blacks, the formation of Fedsem was in line with contemporary government policy for:

[t]he Minister expects the churches if possible to keep to the principle of ethnic grouping in any theological schools they establish, and hopes that this may be possible by the co-operation of various churches to make possible several institutions for the various language groups. But if you want to have all your language (ethnic) groups in one place you will be allowed to do so (Dr van Zyl, Bantu Education Dept. $2^{\text {nd }}$ September 1959, FedSEm AUC Box35, AUTS 1959-60, UFH, HPAL).

However, the Secretary for Bantu Administration and Development, Dr HWM Eiselen, stated that from the beginning of 1960 'only Xhosa students will be admitted to Fort Hare' (Gqubule 2006:6)!

Gqubule (1977:203) goes beyond this by attributing the kudos for the formation of the Seminary to 'Government pressure' and makes an apt missiological comment:

Nothing has forwarded the ecumenical movement more than Government pressure - forcing the church to be the church and not just a congress of denominations. There is something profoundly disturbing that we have to be prodded by financial, political, social or international pressure to do what as brothers it should be our delight to do 
.... Theological training has been forced into ecumenical patterns. This has happened not because the churches suddenly became ecumenically minded, but because outside forces began to operate on the churches (Gqubule 1977:204).

So Fedsem was formed in the context of 'externally caused difficulties' at Fort Hare according to Rev John Summers (Memorandum on proposed federation of theological institutions at present training non-white students, The Christian Council of South Africa, 3 July 1959, FedSem AUC Box 35, UFH: HPAL). This refers to the effects of Bantu Education which resulted in the resignation of senior black academics i.e. Proffs. Nyembezi, Matthews and Ngcobo. Summers refers to a meeting held on $4^{\text {th }}$ March 1959 where representatives of seventeen churches formed a committee 'to draft proposals for presentation to the churches and missions so that they might come to a decision in principle as to whether they wished to join in a Federation of Theological Institutions'. Summers referred to:

our present adversity providing us a wonderful opportunity of our churches getting closer together, but so far we are like the tail wagging the dog (ie. one or two enthusiasts). The major denominations who might come into this co-operative venture are the Anglicans and Methodists. The Anglicans are all for safeguarding their way of training sharing as it were the minimum of lectures and worship.

Summers was a realist who did not underestimate the difficulties of ecumenical co-operation. He had earlier acknowledged this in correspondence with Bishop Reeves:

I accept of course the fact that the hard realities of our ecclesiastical relationships make it impossible to conceive a united theological work just now. At the same time I believe that our common commitment to the ecumenical movement obliges us to give expression to our real underlying unity so far as it is possible to do so (15 August 1956, FedSem AUC Box 35, AUTS 1959-60, UFH:HPAL).

Dr John Reuling (American Board to Sales, $11^{\text {th }}$ December 1959) referred to Summers': 
fear that the efforts to push forward the proposed scheme for a federation of theological institutions in South Africa may fall apart in disunity, unless there is some driving force at the centre to prevent the various groups from getting bogged down in fantastic arguments about whether they will 'eat in silence or with chatter', or 'pray standing on our heads or on our Presbyterian behinds'.

The possibility of the Lutherans joining the Seminary was discussed at an early stage. Booth (American Board to Sales, $11^{\text {th }}$ December 1959, UFH:HPAL) in a letter to Summers encapsulated the political nature of the problem:

Neither Anglicans nor Lutherans have any interest in real co-operation, let alone union, with the rest of us in this work. But the Anglicans are greatly frightened of government pressure, and are seeking the strength of a united stand. Hence their sense of urgency as well as interest. The Lutherans, on the other hand, have all along been most optimistic about government relations, and still fear nothing of their future. They have a good location in the middle of their own field of work [ie. Natal]. Hence it follows that they will not be the least interested in moving to join us. All the more so since many of them consider the English-speaking churches generally to have provoked unfavourable reactions from government, and would not wish to be linked with us to their own jeopardy.

The Lutherans did not take up the option of joining the Seminary at this stage. Other opportunities were extended to them at a later date (Minute 1036.ix of Meeting of Seminary Council S5126/25/9/78, cf. Minute 1085.g of Meeting of Seminary Council S5367/28/8/79, UFH:HPAL) but these were also to no avail. Here was in essence the problem of denominational traditionalism which was to trouble the seminary all its days. Yet, the possibility of additional financial support from new member churches provided an early inducement towards federation, at least. One objection to separate theological institutions included 'the economic impossibility of establishing theological institutions in three different centres' (Summers to Miller, 12 September 1959[?] FedSem AUC Box 35, AUTS 195960, UFH:HPAL). Things clearly changed by 1993 when Fedsem 
closed! Yet, there were positive reasons for this ecumenical venture. It was noted that developing evangelism depended on a degree of ecumenical co-operation, and further that the same was true of interracial relations in South Africa.

Any attempt to find a defining vision and mission statement for the seminary shared by the churches is difficult. There can be no doubt that the Seminary's founding fathers had a clear ecumenical vision, even if it was not clearly articulated. However, in the course of time, that vision was lost sight of at times and ceased to have the power to guide the Seminary at times of crisis. The central objects of Fedsem as defined in the original Constitution, were largely pragmatic:

a) to provide a central authority through which constituent theological colleges .... can act together;

b) to accept ... other theological colleges as may be entrusted to it by other denominations;

c) to co-ordinate the activities of the ... colleges, to supply ... services ... and to deal with outside bodies in matters in which it is to the advantage of such constituent colleges to act in concert as a single association (Fedsem constitution:1) A Statement of Common Principles was adopted in which, with reference to the churches: ....

(iii) they seek by their joint undertaking to express their brotherhood in Christ and they hope that this act of inter-church cooperation will lead to an increased unity in the body of Christ (Min 27, Provisional Council of the Federal Theological Seminary of SA, 13 July 1961:UPCSA).

However, this third object suggests a situation where a couple marry because the girl is pregnant in the hope that their relationship will actually grow more intimate in time. History was to prove the lie of this in the case of Fedsem. Rev S Mogoba (1980:30), a former tutor at the Seminary, refers to an undated document of the Defining Committee of the Seminary which stated several goals:

1. The goal of leading the church in Southern Africa into authenticity, relevance, unity and non-racialism.

2. The goal of leading South African society into justice and freedom and trust. 
3. The goal of exemplifying this newness in ourselves, of embodying in our structures and in our relationships this community, unity, spirituality, justice and readiness to share and sacrifice.

4. The goal of practicing this in our relationships with the churches and local communities, in both our academic/pastoral involvement, and in our personal relationships.

The outcome of these lofty goals was that, in the long term, there was greater success among the 'South African society' and 'local communities' than 'the church in Southern Africa'. These principles expressed a hope of greater unity but did not go as far as some kind of covenant or practical means for achieving that unity.

\section{ISSUES OF CONCERN TO THE CHURCHES}

Four matters exercised the minds of the participating churches. The first concerned the autonomy of the Seminary. Agreement was reached guidance having been sought from a memorandum prepared by Bishop Lesslie Newbigin in 1960 (Min. 166, Federal Seminary Committee, 1 December 1960, Box 35, File, FedSem, AUC, AUTS, 1959-1961, UFH:HPAL):

1. The Christian Church has a fundamental duty and responsibility for the training of its own ministry. The committee wish to state that this is an issue upon which there can be no compromise and for which, whatever the consequences, the Church must make its own provision.

2. The Churches therefore agree to provide themselves with the same means of training for their ministries which will be entirely autonomous and shall not depend in any respect, upon any state controlled university.

This matter focussed on the sensitive relationship with the adjacent University of Fort Hare. Concern was expressed by Anglicans and Congregationalists that this site was too close to Fort Hare and that the autonomy, integrity and freedom of the Seminary might be compromised. They adopted a policy of non-co-operation with Fort Hare while the Methodists and Presbyterians had lengthy ties with Fort Hare and were less inclined to sever this relationship entirely. Some Anglicans favoured a more moderate approach to the matter of the relationship with Fort Hare but Canon James Calata and others remained steadfast in their opposition 'a link with Fort Hare and the 
Seminary ... would create disciplinary difficulties and would be in contravention to the fundamental principles' (Draft Memorandum 5.b, Meeting of Council S/182/29/9/63, UCCSA). While agreement proved to be elusive, assurances were given that, as far as possible, the seminary would be independent and autonomous.

The second matter concerned retaining denominational distinctiveness in training ministers in a federal structure. Clearly the churches wanted to train their own ministers for their own denominations and not for some future united church. This implied a limited view of ecumenism and its future. Architecturally, each college would have its own buildings and amenities. It would also have its own Principal and staff with its own regulations for entry, discipline and preparation for ordination. However, despite an early intention to teach some courses separately, in reality all teaching was done at the seminary level.

Another concern centred on the politics of organisation, with special attention being given to the siting of the campus, a particularly sensitive matter both in terms of church and national politics. Significant criteria listed included:

security of tenure and operation; accessibility; suitability for various detailed purposes of the institution; climate; natural surroundings; relative level of building costs; price of land; intellectual stimulation in the surrounding area; opportunities for practical field work; medical services; denominational neutrality on the site (Message to the Participating Churches Concerning Plans for a Federal Theological Seminary,FedSem Committee, 15/6/60, Box 35, File, FedSem, AUC, AUTS, FedSem Committee minutes, 1959-1961, UFH:HPAL).

Eventually, a site adjacent to the University of Fort Hare was agreed upon. This had been offered free of charge by the Church of Scotland and had been donated by Chief Tyhali together with his senior brothers Sandile and Maqoma, sons of Chief Ngqika, in 1855 for educational, medical and other missionary purposes (Shepherd 1971:12). Part of this land was given for building the South African Native College at Fort Hare. This provided for the realisation of a vision of $\mathrm{Dr}$ James Stewart of Lovedale which was brought to fruition under his successor Dr James Henderson. 
Finally, security of tenure was a concern because the formation of the seminary was in direct opposition to the apartheid policy of the government. Assurances were needed that it would be secure in the light of the great cost of erecting buildings and providing services, and also that the siting of Fedsem would not contravene the Group Areas Act. This was important. The discovery that Fort Hare itself contravened the Group Areas Act, placed Seminary delegates in a strong negotiating position since this discovery revealed that Fort Hare needed to gain access across Lovedale land to comply with the Act (Cameron 1984:29-30) by being within or adjacent to an area zoned for black occupation. Father Aelred Stubbs, first Principal of St Peter's College referred to this 'Black island in a white sea' (Stubbs. Personal notes on the history of the seminary in Cameron 1984:30):

The Seminary deputation reacted to this startling disclosure with inspired promptness. It affected the whole tone and temper of the interview which became much more like horse trading than any of us could have conceived possible.

A deal was struck in which the government would approve the building of the seminary in return for the Church of Scotland being approached with a view to allowing Fort Hare to be linked to a black area (Minutes of a meeting held in House of Assembly, Cape Town, 21 June 1961, Appendix to minutes of Provisional Council Meeting, 13 July 1961, cf. Minute of first meeting of Executive Committee, 3 October 1961, UFH:HPAL).

Further discussion included the issue of possible expropriation. The Secretary of the Department of Bantu Administration and Development affirmed that '... the Government would not wish to exercise rights of expropriation, even if it had the legal right to do so'(Detailed record of the meeting between the Government and the Seminary deputation, 21/6/1961. Signed by both parties as an accurate record of the proceedings, in Cameron 1984:30). One might wonder then, what the government expected in return for their cooperation? First, they needed a corridor into a black area. Then, they hoped that the Seminary would send students to study in the Faculty of Divinity in order to obtain a recognised degree despite the Seminary's affirmation of its autonomy. The Seminary, however, had a preference for offering its own degree award course. This would 
become a source of grave tension in subsequent years. Perhaps a misleading intention had been declared by Bishop Selby Taylor when he said:

The particular site was chosen, because it was important in the thinking of the Churches that the highest training for the ministry should be in proximity with a centre of university training. The Council members were not sure at the present time as to what extent they would make use of the University College of Fort Hare facilities, but their long term hope would be to make both direct and indirect use of them (ibid).

Whatever, the level of understanding which existed between the Churches and the Government, certainly the churches themselves were not unanimous in their view of this matter. The end result was that the churches achieved sufficient assurances which enabled them to proceed with the project.

\section{BUILDINGS}

From 1961 when the site was chosen the matter of building the seminary became a priority. No services were available on the site and the first to be provided so building could begin was water. An agreement was made that Vos, Lane and Vincent would be the sole architect (Minute E93(c) of Executive Committee, 8 November 1962, UFH:HPAL). Each college was free to design its own buildings with the proviso that the same basic materials would be used to produce a degree of conformity. Russell Enterprises was awarded the building contract and work began first on John Wesley and St Peter's Colleges in June 1962. These colleges and the central buildings (minus the library) were completed in eight months in time for the opening ceremonies in spite of many difficulties while Adams United and St Columba's Colleges were completed later, temporary arrangements having been made to accommodate their students. The Congregationalists camped at Lovedale Bible School while the Presbyterians shared St Peter's College.

\section{THE OPENING}

The first students were enrolled at the Federal Theological Seminary of Southern Africa at the beginning of March 1963. At this stage the Anglican college, St Peter's and the Methodist college, John Wesley 
were ready for occupation while the Presbyterian, St. Columba's, and Congregationalist, Adams United, colleges were not.

When it came to the details of the actual opening of FedSem, there was a suggestion that 'there should be an opening ceremony for all the colleges at the same time as an expression of unity' (FedSem Council Minutes, Box 1, Min E65 re Min E51[c], E4/S23/11/9/62:1, UFH). This was referred to the Council which later noted 'the following dates for the opening ceremonies' (emphasis mine) (Min 125 re Min E65, C2/S34/5/12/62, UFH: HPAL). This was in addition to a Seminary opening on yet another date! (Minute E1 31, E4/S50/26/2/63, UFH: HPAL). There was no further comment or discussion on the matter.

The official opening took place in the afternoon of $23^{\text {rd }}$ September 1963 at an open air ceremony with 1200 people present. At the opening of the Seminary buildings, Bishop Selby Taylor officiated, while Rev Frederick Read, Principal of Epworth Theological College, Zimbabwe, gave the Address on the problem of status in the Ministry. A Stone of Commemoration was laid with the inscription:

This stone commemorates with gratitude all those who, for more than 100 years, have been trained for the

Christian ministry in the Colleges now constituting this Seminary (Minute E164(vi), Executive Committee, 26 June 1963, UFH: HPAL).

St Columba's College was opened on $9^{\text {th }}$ June 1963 by Rev RHW Shepherd and Rev John Summers, Principal gave the Address.

Adams United College was opened on the morning of 26 September 1963 by Rev JK Main, while Dr Edgar Brookes gave the Address.

John Wesley College was opened on 23-24 May 1963 by Rev DP Dugmore, while Professor de Wolf of Boston gave the Address.

\section{COURSES OFFERED}

The courses pursued were determined by the requirements of each participating denomination as well as by entry qualifications.

\subsection{Certificate in Theology}

This was a three year post Junior Certificate course which was designed with the less academically inclined student in mind who 
demonstrated a clear level of spirituality and a call to ministry. The syllabus followed was similar to the Diploma in Theology but was examined at a lower level of attainment. The Academic Board was concerned that this should be the lowest qualification necessary 'to meet the needs of an increasingly educated society'(Minute A1316.1 (AB) of Seminary Council S1344/25/8/67, UFH: HPAL).

\subsection{Diploma in Theology}

This was also a three year course for candidates with a Senior Certificate or equivalent qualification approved by the Joint Board for the award of the Diploma. This course was followed by a number of colleges in southern Africa and common high standards were maintained through a system of external moderation.

\subsection{Associateship of the Federal Theological Seminary (AFTS)}

This was a three year course which was the equivalent of a first university degree course. Entry qualifications were the same as for South African universities. Not being a government institution, Fedsem could not award degrees. This course was deliberately established a high standard in an attempt to secure international recognition which it did in 1968 when a Fedsem graduate was accepted for post-graduate studies at the University of London. Many Fedsem AFTS alumni have gone on to achieve a high degree of academic recognition.

\subsection{Informal Curriculum}

Although not on the menu of courses offered, there was an alternative curriculum on offer at Fedsem which was derived from its 'prophetic history of resistance and even confrontation with the Apartheid government - a history it could not shake off' (Maluleke 2002:5). At an official level, this approach:

was hammered out of action, in the worship life of the community and its struggle for liberation. Fedsem provided a spirituality for the liberation struggle. Its worship life went beyond the personal to encompass the community and beyond race to embrace humanity in its entirety. It was in the worship life of Fedsem and in the spontaneous eruption of Amadodana singing after the chapel that a new ethos of the church was created and continued to be reshaped over many decades of theological training at Fedsem (Khabela 1997:iii). 
This ethos emerged in this alternative community in which race, ethnicity, gender, denomination and tradition transcended the social and ecumenical boundaries imposed externally. It prepared students to be equipped:

with lasting skills in articulation - with skills of research so that we know how to pursue knowledge for ourselves - with skills to think independently and act independently and enjoy doing so rather than be threatened by it and with skills to be leaders on our own right and not be perpetual followers of others (Finca 1998:7).

This curriculum was subliminally subversive and originated in exposure to the range of political theologies which were current in the USA, Europe and Africa and were beginning to be promoted. Students were encouraged to think for themselves, reach their own conclusions and strive towards attaining their full intellectual potential. At an unofficial level there were the effects of the living arrangements and extra-curricular activities including student meetings, sports, celebrations and drama. These 'encouraged negotiation, tolerance and understanding for traditions other than one's own and people other than one's own' (ibid:6).

\section{LIBRARY}

The Fedsem library became one of the finest theological libraries in South Africa: 'We were able to boast of one of the best equipped libraries on the continent'(Ndungane 1973:3). It was a special project of Brother Charles Coles, CR. In addition, each college had its own library.

\section{ADMINISTRATION}

Each College had a Principal who was appointed by the churches. And the churches appointed a further three lecturers to each college. This meant the Seminary had twelve theological lecturers. Each college through its college board was responsible for admissions, accommodation and allowances. There was an unwritten policy of non-interference with other colleges' affairs. With regard to the Presidency of Fedsem, 'The Council may appoint to this office any person whom it deems fit'(Constitution and By-Laws 3(b), 22 November 1961. Alice: Lovedale Press:2).

However, in practice, College Principals took turns to be Seminary President for a two year period. The President is the focus 
of a common loyalty to the Seminary and is responsible for the coordination of the entire work of Fedsem and for liaison between the churches and colleges. The Seminary Council, which was made up of representatives from the Churches' college boards, appointed an English lecturer.

The first Chair of Council was Archbishop Selby Taylor; Stephen Wright was Registrar, and John Summers was President. Together they established the ethos of the Seminary in its early days.

\section{EARLY MOVES TOWARDS INTEGRATION}

From the beginning of the discussions on the formation of the Fedsem, the discussion about integration had been raised. This was natural as the result of the various combinations of efforts at cooperation that had been experimented with almost from the beginning of theological education in South Africa amongst those churches which became members of Fedsem. This matter had been raised in 1959-1960 prior to the opening of the campus and in 1961 there had been extensive discussions between the Presbyterians and Congregationalists. By 1972, it was raised again and this time consideration was given to closer links with the Methodists. 'The Anglicans may have changed, but they would not agree to taking part in a Federal Seminary if they were the only college other than a united college'. One fear expressed was that 'if after trying to work together you split apart it will prejudice such future attempts'(Letter, Summers to Brown, 18/1/72: Duncan papers).

\section{CONCLUSION}

There was no programme of implementation of full unity at Fedsem and the subsequent history of Fedsem demonstrates that the churches, by and large, wanted to maintain the status quo, with few exceptions. Any vision was hazy at the least: 'There has been in the minds of leaders of several of our churches in recent years the desire to work more closely with other churches...' (Appendix 1:1 to Min 27 above, 22 June 1961, UFH: HPAL). The press statement released was no clearer: 'It is believed ... that there will be a growth of understanding and fellowship between the participating churches' (Appendix A, ref. Min 49 of Council Meeting of 13/7/61, UFH: HPAL). One gets a distinct impression that any ecumenical benefit from the existence of the seminary would be a by-product of the experiment. Yet, there was a desire for an autonomous theological institution which could provide an academic atmosphere, 
comparable with any university, where ministers could be trained in free critical thinking apart from the educational philosophy of Bantu education.

The greater necessity was to safeguard existing denominational theological training in a situation of dispossession. Adams United College and St Peter's College had been given notice to quit their sites and the Methodists and Presbyterians 'knew that the government's Fort Hare Transfer Bill of 1959 would be bound to disrupt their work of theological training' (Appendix A, ref. Min 49 of Council Meeting of 13/7/61, UFH: HPAL) and especially their power to appoint theological tutors. The Bantu Education Act had stripped the churches of missionary influence in education. The missionary response was ambivalent as, on the one hand, they were grateful for financial assistance to continue the work they had initiated and on the other, they vehemently opposed the philosophy of Bantu education. All of this drew the English-speaking churches together.

The lack of an adequate and appropriate vision was critical for Fedsem. Kinoti (in Njoroge 1996:17) defines vision as 'a deep dissatisfaction with what is and a clear grasp of what could be. Vision begins with indignation over the status quo and grows into the earnest quest for an alternative'. Any dissatisfaction and indignation in Fedsem's case had little to do with the ecclesiastical or ecumenical situation. It had more to do with the political context. That may explain why there was so little enthusiasm for theological unity and much more for a changed society at this time. That is where the vision lay and that was what Fedsem worked towards in a more committed manner.

\section{Consulted literature}

\section{Primary sources}

Agape 1973. (Fedsem journal) 1(10, September). Lovedale: Fedsem.

Brown G 1973. Foreward, Agape, 1(10, September), 1.

Correspondence of Graeme Brown: in possession of author.

Howard Pym Africana Library, University of Fort Hare(HPAL): FedSem papers.

St Columba's College: Alice, CP, South Africa. 1965 Alice: Lovedale Press

Stewart J 1906. Dawn in the Dark Continent: Or Africa and its missions. Edinburgh: Oliphant, Anderson \& Ferrier. 
United Congregational Church of Southern Africa (UCCSA): FedSem papers. Uniting Presbyterian Church in Southern Africa (UPCSA): Fedsem papers.

\section{Secondary sources}

Booth W R 1973. How we came together, in Stubbs A (ed.). The Planting of the Federal Theological Seminary in Southern Africa. Lovedale: LovedalePress:1-5.

Cameron R D T 1984. Some Political, Ecumenical and Theological Aspects of the History of the Federal Theological Seminary. 1963-1975. MA dissertation: University of Cape Town.

De Gruchy J W 1996. From the Particular to the Global: Locating our task as theological educators within the viability study process. Bulletin for Contextual Theology in SA and Africa. 3 (October), 20-24.

-, 1997. Grappling with a colonial heritage: The English-speaking churches under imperialism and apartheid in Elphick \& Davenport, 155-172.

Elphick R \& Davenport R 1977. Christianity in South Africa. A political, social and cultural history. Cape Town: D Philip Publications.

Finca B B 1998. A New Vision for Fedsem in the $21^{\text {st }}$ Century in Khabela \& Mzoneli (ed.), 1-9.

Gqubule T S N 1977. An examination of the theological education of Africans in the Presbyterian, Methodist, Congregational and Anglican churches in South Africa from 1860-1960. PhD thesis. Grahamstown: Rhodes University.

-, 2006. The Story of the Federal Theological Seminary. Unpublished manuscript. Port Elizabeth.

Khabela M G 1997. Introduction in Khabela MJ \& Mzoneli ZC (ed.) 1998, iiivi.

Khabela M J \& Mzoneli Z C (ed.) 1998. Khabela MJ \& Mzoneli ZC (ed.) 1998. Perspectives on Ubuntu: A tribute to Fedsem. Alice: Lovedale Press.

Lombaard C (ed.) 1999. Essays and Exercises in Ecumenism. Pietermaritzburg: Cluster.

Madise M J S 2000. The Development of the Black Ministry in the Methodist Church of South Africa from the Apartheid Era to the Post Apartheid Era. MTh dissertation. Pretoria: UNISA.

Maluleke 2002. The HIV/AIDS Road to Damascus in Theological Education, INATE Conference, UKZN.

Mogoba M S 1980. Theological education in Africa. Missionalia 8/1, 27-31.

Mouat C 1999. Ecumenical theological education in South Africa: FEDSEM and TEEC(SA) as case studies in Lombaard (ed.), 217-234.

Ndungane W N 1973. Jubilate, Agape, 1(10), 3.

Ndungane N 1998. Theological Education in the Last Fifty Years in Suggit \& Goedhals [ed.], 107-115. 
Njoroge N 1996. Ecumenical Theological Education and the Church in Africa Today. Bulletin for Contextual Theology in South Africa and Africa. 3/3, October, 15-19.

Shepherd R H W 1971. Lovedale, South Africa: 1824-1955. Lovedale: Lovedale Press.

Stubbs A (ed.) 1973. The Planting of the Federal Theological Seminary in Southern Africa Lovedale: Lovedale Press.

Suggit J \& Goedhals M (ed.) 1998. Change and Challenge: Essays Commemorating the $150^{\text {th }}$ Anniversary of the Arrival of Robert Gray as First Bishop of Cape Town [20 ${ }^{\text {th }}$ February 1848]. Marshalltown: CPSA.

Wing J 1990. Developments within the Seminary. Johannesburg: UCCSA Archives. 